\section{Lalka z łóżka 21 Đorđa Lebovicia, czyli trauma wojny i opresja wolności}

Barbara Czarnecka, Katarzyna Taczyńska

TEKSTY DRUGIE 2018, NR 5, S. 45-64

DOI: $10.18318 /$ td.2018.5.3

Gdy wróciłem z obozu do życia, widziałem przed sobą dwie możliwości - zapomnieć lub mówić. Pierwszego nie mogłem, co oznaczało, że musiałem drugie

Đorđe Lebović1

Niemal dekadę temu w jednym z krakowskich dzienników ukazała się rozmowa dziennikarza z Agnieszką Weseli, badaczką studiującą zagadnienie prostytucji w obozach koncentracyjnych. Wywiad poruszał nie tylko historyczne fakty związane z istnieniem systemu Sonderbau, czyli obozowych "domów publicznych", w tym z burdelem funkcjonującym w bloku 24a obozu Auschwitz I, ale i sprawę „drażliwej” pamięci o nich.

1 "Kad sam se vratio iz logora u život, video sam pred sobom samo dva izbora - zaboraviti ili govoriti. Prvo nisam mogao, znači drugo sam morao", Đ. Lebović Umesto predgovora (Iz piščeve beležnice), w: tegoż Tetralogija, BIGZ Školstvo, Beograd 2007, s. 12. Wszystkie tłumaczenia cytowanych fragmentów twórczości Đorđa Lebovicia są naszego autorstwa - B.Cz., K.T.
Praca Katarzyny Taczyńskiej została wykonana w ramach projektu badawczego nr 2015/16/S/ HS2/ooog2 ze środków Narodowego Centrum Nauki.

Barbara Czarnecka dr hab., Wydział Polonistyki UJ, redaktorka książek zbiorowych oraz tekstów Jerzego Pietrkiewicza, współautorka bibliografii nowojorskiego "Tygodnika Polskiego", autorka monografii Ruchomy na szali wagi. Lechoń homotekstualny (2013) oraz Kobiety w lagrze.Zapis doświadczenia (2018).

Katarzyna Taczyńska - adiunkt w Instytucie Filologii Słowiańskiej UAM przy realizacji projektu Pamięć (o) przemocy. Kulturowa historia kobiet w serbskim i chorwackim dyskursie historycznym i literackim wXX wieku. Autorka monografii Dowcip trwajacy dwa i pół roku. Obraz Nagiej Wyspy w serbskim dyskursie literackim i historycznym końca XX i początku XXI wieku. 
- Chciałaby Pani, żeby na bloku 24, przy symbolicznej bramie z napisem „Arbeit macht frei” pojawiła się tablica informująca o tym, co się w nim działo? - Tak, chciałabym, żeby się tam znalazła podobna tablica. Chronimy obraz obozu kosztem pewnych osób. Kosztem kobiet, które w tym domu publicznym pracowały. One też są ofiarami, a nadal nie są rozpoznane jako ofiary, bo mówi się o nich jedynie jako o dziwkach i kolaborantkach. A to nieprawda. ${ }^{2}$

Prowokacyjność pytania o umieszczenie na terenie Muzeum Auschwitz-Birkenau tablicy upamiętniającej istnienie obozowego puffu pozostaje aktualna i odzwierciedla problem, który dotyczy polskiej, i nie tylko polskiej, kultury pamięci po II wojnie światowej.

Krótko po jej zakończeniu zjawisko obozowej, zinstytucjonalizowanej prostytucji jako pracy przymusowej zostało wyłączone z dyskursu postholokaustowego. „Wpływ na taki stan rzeczy miały istniejące jeszcze w czasie wojny dwa mechanizmy: tabuizacja i stygmatyzacja zjawiska podtrzymywane przez oprawców, po wojnie również przez byłych więźniów. Kobieta «przymuszona» do pracy w obozowym domu publicznym, a także mężczyzna odwiedzający puff nie zasługiwali w powszechnym mniemaniu na status ofiary"3.

W nowoczesnej formie podjęła problem artystka sztuk wizualnych Anna Baumgart, która wyreżyserowała wideo Świeże wiśnie, o teatralnej konwencji dokumentu i zapisu z systemowych ustawień hellingerowskich. Film opowiada o kobiecym doświadczeniu przymusowej prostytucji w lagrach oraz jego późniejszej tabuizacji, a także stygmatyzacji i hierarchizacji tych kobiet jako ofiar. Produkcję prezentowano w Centrum Artystycznym w Falstad w Norwegii, gdzie znajdował się jeden z niemieckich obozów koncentracyjnych ${ }^{4}$. Jednak już w latach 6o. zagadnienie to podjął serbski dramatopisarz Đorđe

2 Jarosław Zalesiński rozmawia z Agnieszką Weseli, Noce i dnie w obozie Auschwitz, "Gazeta Krakowska" 11.02.2010, http://www.gazetakrakowska.pl/artykul/220600,noce-i-dnie-w-obozie-auschwitz,3,id,t,sa.html (22.02.2018).

3 J. Ostrowska Prostytucja jako praca przymusowa w obozach koncentracyjnych, https://www. holocaustresearch.pl/index.php?show=353 (18.04.2018).

4 Zob. Appendix towarzyszący filmowi, który stanowi "making of projektu oraz rozwinięcie wątku prostytucji obozowej", A. Baumgart Świeże wiśnie. Appendix, Filmoteka Muzeum nad Wisłą, https://artmuseum.pl/pl/filmoteka/praca/baumgart-anna-swieze-wisnie-appendix (02.04.2018). Zob. także dyskusję o filmie K. Bojarska, I. Kurz Na progu empatii. Dyskusja o filmie Anny Baumgart "Świeże wiśnie”, "Obieg” 3.03.2011, http://archiwum-obieg.u-jazdowski.pl/rozmowy/20441 (02.04.2018). 
Lebović, który w (post)jugosłowiańskim teatrze i kinematografii, a także w historii literatury zajmuje miejsce szczególne. Dodać należy, że również w kulturze polskiej twórczość tego autora bywała obiektem zainteresowania, choć dziś raczej mało kto pamięta o spektaklach wyreżyserowanych na podstawie jego dramatów 5 .

Đorđe Lebović (1928-2004) był nie tylko dramatopisarzem, ale i dziennikarzem radiowym (Radio Beograd) i prasowym (satyryczne czasopismo "Jež") oraz scenarzystą filmowym (autor m.in. scenariusza kultowego filmu Walter broni Sarajewa [Valter brani Sarajevo] z 1972 r.) $)^{6}$. Jednak dla większości krytyków i odbiorców istniał przede wszystkim jako autor dramatów telewizyjnych i radiowych, których słuchano w całej Jugosławii, również dlatego, że dotykały one szczególnie drażliwych kwestii związanych z pamięcią o II wojnie światowej. Zawarte w tych ramach dramatopisarstwo moralnego niepokoju Lebovicia wyznaczyło też nowe tematy dyskusji. Napisaną przez niego we współpracy z Aleksandrem Obrenoviciem sztukę Niebiański oddziat (Nebeski odred) z 1956 roku uznaje się za przełomową czy też graniczną (to opinia m.in. Predraga Palavestry ${ }^{8}$ ) dla nowoczesnej dramaturgii jugosłowiańskiej i serbskiej. Niebiański oddział wprowadził nieheroiczną wizję wojny, zwrócił uwagę na tragiczność wyborów, ludzką bezradnośç 9 . Jest to ponadto

5 W 1959 roku (9 kwietnia) W Teatrze Zagłębia w Sosnowcu odbyła się premiera sztuki wyreżyserowanej przez Marko Foteza na podstawie dramatu Lebovicia i Aleksandra Obrenovicia Nebeski odred (Himmelkommando); zob. Encyklopedia Teatru Polskiego, http://www.encyklopediateatru.pl/osoby/57047/zygmunt-stoberski (2.04.2018). Inny dramat Lebovicia (Haleluja) wyreżyserował Kazimierz Dejmek, premiera odbyła się w Teatrze Narodowym w Warszawie 17 września 1964 roku; zob. Encyklopedia Teatru Polskiego, http://www.encyklopediateatru.pl/ przedstawienie/9177/alleluja (2.04.2018).

6 Lebović ponadto pracował w Belgradzkim Teatrze Dramatycznym, w którym w okresie od 1979 do 1981 roku obejmował stanowisko dyrektora artystycznego w zakresie dramatu. W latach 1976-1978 pełnił funkcję (jako pierwszy w historii) przewodniczącego Stowarzyszenia Pisarzy Dramatycznych Serbii (Udrženje dramskih pisaca Srbije), kontynuatora założonego przez Branislava Nušicia Stowarzyszenia Jugosłowiańskich Autorów Dramatycznych.

7 Zob. np. wspomnienia Đorđa Malavrazicia, Audio i Foto Arhiv Simić, http://www.audioifotoarhiv.com/gosti\%20sajta/DjordjeLebovic.html (10.02.2018).

8 Cyt. za: S. Selenić Savremena srpska drama, w: Antologija srpske drame, Srpska književna zadruga, Beograd 1977, s. XXI.

9 П. Палавестра Јеврејски писци у српској књижевности, Институт за књижевност и уметност, Београд 1998, s. 148-149. Dramat Lebovicia w 1957 roku otrzymał prestiżową nowosadzką nagrodę teatralną imienia Jovana Steriji Popovicia (Sterijina nagrada). W kolejnych latach Lebović otrzymał ją jeszcze za dramat Haleluja (w 1965 roku) i Viktorija (w 1968 roku). 
pierwszy dramat w socjalistycznej Jugosławii, który otwarcie podejmował problematykę Holokaustu ${ }^{10}$. Wyjątkowy charakter tekstu wzmacnia fakt, że Lebović rekonstruuje w nim własne doświadczenia z pobytu w Auschwitz, do którego trafił jako piętnastolatek wraz z transportem Żydów z Wojwodiny 1 czerwca 1944 roku $^{11}$. Bohater utworu przedstawiony jest jako A-12750 i nosi rzeczywisty numer obozowy Lebovicia. Utwór odtwarza też historię członka Sonderkommanda, polskiego Żyda, którego poznał on w trakcie demontażu budynków krematorium ${ }^{12}$. Przedstawione zdarzenia są zatem artystyczną transpozycją obozowej biografii serbskiego dramatopisarza ${ }^{13}$. Doświadczenia z tamtego okresu zostały wiele lat później zrelacjonowane przez niego w rozmowie z cenionym dziennikarzem i publicystą Jašą Almulim. Wywiad zatytułowany Widziatem komore gazowa (Video sam gasnu komoru) ukazał się w 2002 roku w zbiorze Żywi i martwi: rozmowy z Żydami (Živi i mrtvi: razgovori sa Jevrejima $\left.{ }^{14}\right)$.

Lebović cieszył się okresową popularnością, spektakle wykreowane na podstawie jego tekstów prezentowano w Czechosłowacji, Niemczech, Polsce, a nawet Michigan ${ }^{15}$. Jednak, jak zauważa Teofil Pančić, autor słowa wstępnego do autobiografii pisarza, jest on autorem dzisiaj raczej zapomnianym ${ }^{16}$, a jego

Dramat Nebeski odred posłużył również jako scenariusz do filmu z 1961 roku pod tym samym tytułem, w reżyserii Boška Boškovicia i Iliji Nikolicia. Więcej na temat filmu zob. N. Daković (Im) possible Witness: the Revelation of the Himmelcommando, w: Representation of the Holocaust in the Balkans in Arts and Media, red. Nevena Daković, Faculty of Dramatic Arts, Institute for Theatre, Film, Radio and Television, Diskurs, Belgrade 2014, s. 1-8.

S. Vervaet Staging the Holocaust in the Land of Brotherhood and Unity: Holocaust Drama in Socialist Yugoslavia in the 1950 s and 1960s, "The Slavonic and East European Review" 2014 No. 2, t. 92, s. 228.

V. Pavković Pogovor: Nad sećanjima Đorđa Lebovića, w: Đorđe Lebović Semper idem, Narodna knjiga - Alfa, Beograd 2005, s. 413. Lebović był również więźniem obozów w Sachsenhausen i Mauthausen.

S. Vervaet Staging the Holocaust..., S. 233.

Dramat do dziś bywa grywany w teatrach obszaru byłej Jugosławii. 12 maja 2017 roku odbyła się premiera spektaklu w reżyserii Juša A. Zidara na scenie teatru Slovensko ljudsko gledališče Celje. Zob. Slovensko ljudsko gledališče Celje, http://www.slg-ce.si/domov/ostalo/seznam-iger/ nebeski-odred (10.02.2018). J. Almuli Živi i mrtvi: razgovori sa Jevrejima, S. Mašić, Beograd 2002. Ђ. Лебовић Војник и лутка. Драма у два чина, s. 195, https://www.rastko.rs/drama/ssd/ ssd21/d_lebovic.pdf(10.02.2018). 
dorobek nie stał sięjak dotąd przedmiotem gruntownej historycznoliterackiej refleksji ${ }^{17}$. Krokiem w kierunku przywołania twórczości Lebovicia okazała się pośmiertna publikacja jego autobiografii zatytułowanej Semper idem (2005), nad którą pracował on do końca swojego życia. Zainicjowane przez żonę pisarza, Zlatę Lebović, opracowanie i pierwsze wydanie tej obszernej, choć nieukończonej „kroniki dzieciństwa” (w rękopisie brakowało trzech ostatnich rozdziałów), której akcja rozgrywa się między Zagrzebiem i wielonarodowym Somborem, nie zwróciła większej uwagi czytelników i krytyki. Jednak kolejna edycja, przygotowana przez serbskie wydawnictwo Laguna, kojarzone przede wszystkim z literaturą popularną (choć w ostatnich latach publikujące również serbskich klasyków i współczesne, ambitniejsze dzieła literackie), wskrzesiła książkę w edycji, która dotarła do szerszego grona odbiorców i wzbudziła ich zainteresowani ${ }^{18}$. Publikacja ta przypomniała szerszej publiczności o postaci Lebovicia i ukazała go jako prozaika miary innego, wybitnego jugosłowiańskiego i serbskiego intelektualisty i pisarza o żydowskich korzeniach, Danila Kiša ${ }^{19}$.

W Polsce dość nieoczekiwanie odświeżyły dramatopisarstwo Lebovicia dwa niedawne wydarzenia, popkulturowe i kulturalne. Pierwsze z nich to polska edycja serii komiksowej Partyzanci, wydawanej w byłej Jugosławii w latach 1977-1989, której głównymi bohaterami są brytyjski major Dragon i jugosłowiańska partyzantka o imieniu Skierka. Autorem scenariusza cyklu jest właśnie Đorđe Lebović. Wersja polska ukazała się w 2015 roku nakładem wydawnictwa Elemental ${ }^{20}$.

Drugie zdarzenie, którym jest spektakl teatralny, bezpośrednio wiąże się z głównym tematem niniejszego artykułu - dramatem autorstwa Lebovicia Lalka z tóża numer 21 (Lutka sa kreveta broj 21). Tekst ten powstał w latach 60., pierwsza jego telewizyjna prezentacja odbyła się w Jugosławii w roku 1966²1.

S. Vervaet Staging the Holocaust..., S. 228.

Semperidem (Uvek isto), YouTube 20.03.2017, https://www.youtube.com/watch?v=7Sen1V2tTaA (10.02.2018).

T. Pančić Fascinantna hronika..., s. 543-544.

"Partyzanci to kawałek solidnego komiksu wojennego. Trochę innego od tego, do jakiego przyzwyczaiła nas amerykańska popkultura, czy brytyjskie picture libraries takie jak Commando", Gitarą rysowane, Partyzanci. Wydanie zbiorcze, t. 1, http://gitararysowane.pl/partyzanci-wydanie-zbiorcze-t-1/(23.02.2018).

21 Napisany jako dramat telewizyjny tekst został po raz pierwszy zrealizowany i przedstawiony w 1966 roku w produkcji Radio-televizija Srbije (RTV Beograd) w reżyserii Jovana Konjovicia. 
W Polsce sztuka serbskiego dramatopisarza nie doczekała się wystawienia. Co prawda w roku 1970 TVP zrealizowała spektakl według tekstu Lebovi$\mathrm{cia}^{22}$, jednak nigdy niewyemitowany trafił on do telewizyjnego archiwum pomiędzy inne kontrowersyjne wówczas „półkowniki”. O dramacie serbskiego autora przypomniała w 2017 roku Magda Fertacz, włączając sceny z Lalki z łóżka numer 21 do teatralnej realizacji Puppenhaus. Kuracja, którą prezentował warszawski Teatr Rozmaitości (premiera w kwietniu 2017, reżyseria Jędrzej Piaskowski). Fragmenty polskiego przedstawienia z 1970 roku pojawiły się tutaj w postaci zapętlonego (odtwarzanego wciąż od nowa) urywka spektaklu wyświetlanego jako tło nowoczesnej scenografii Puppenhaus. W efekcie dramat Lebovicia, pozbawiony głębszej refleksji, stał się rodzajem efektu estetycznego czy scenicznego. Związki między sztukami są oczywiste - Puppenhaus podobnie jak Lalka z tóżka 21, tylko w szerszy, co znaczy tutaj wielowątkowy sposób podejmuje kwestię społecznej pamięci oraz wytworzonej przez nią opresji kulturowej, którą nazwać można opresją heroistyczną.

Tekst Lalki z łóżka numer 21 został pomyślany przez Lebovicia jako przyszły scenariusz spektaklu telewizyjnego, świadczą o tym wskazówki dotyczące ustawienia kamery, uwzględnienie w tekście tzw. czołówki oraz studyjny charakter całości. Akcja dramatu rozgrywa się w mieszkaniu głównej bohaterki Vilmy Rajner-Jelinek. W sztuce biorą udział jeszcze dwie postaci Emil Grabner oraz Jelinek, mąż Vilmy.

Po dwudziestu latach od zakończenia wojny Emil Grabner, obecnie adwokat na cichej prowincji, dawniej esesman i szef burdelu dla niemieckiego wojska, w którym przymusowymi prostytutkami były obozowe więźniarki (domyślamy się, że z Auschwitz-Birkenau), odnajduje jedną z nich - Vilmę, wówczas 16-letnią Vilmę Rajner, obecnie Rajner-Jelinek, lekarkę pediatrę. Trafia do jej mieszkania, aby przekonać kobietę do zachowania milczenia w toczącym się właśnie - w związku z nim jako zbrodniarzem wojennym śledztwie. Dwie dekady wcześniej, zaraz po uwolnieniu z lagru Vilma złożyła pisemne zeznanie oskarżające Grabnera, jednak, aby mogło ono teraz zostać włączone do aktu oskarżenia, należy je uwierzytelnić, potrzebny jest aktualny

Główne role zagrali wówczas: Ljubiša Jovanović (Grabner), Vesna Krajina (Vilma), Branko Pleša (Jelinek). Zob. Lutka sa kreveta br. 21, http://www.imdb.com/title/tto278549/ (10.02.2018); http://www.imdb.com/title/tto278549/ (8.02.2018). Warto zwrócić uwagę, że tekst powstał najprawdopodobniej krótko po wydarzeniu, jakim był jerozolimski proces Adolfa Eichmanna. 
podpis Vilmy Rajner-Jelinek. Kobieta ma rodzinę - męża i dwójkę dzieci, ma też tzw. ułożone życie, zawodową i materialną stabilizację (jest „wręcz idealnie" - jak powiada Niemiec); brakuje jej natomiast poczucia wyrównania rachunków, wymierzenia sprawiedliwości Grabnerowi, o którym wcześniej myślała, że nie żyje. Jednak, jak wyłuszcza jej były esesman, zeznania Vilmy nie tylko pozwolą go skazać na zaledwie symboliczną, nieodzwierciedlającą jego przewinień karę, ale i postawią w stan nieodwracalnego publicznego oskarżenia ją samą, jako lagrową prostytutkę, ,esesmańską dziwkę". Grabner w obecności męża Vilmy - Jelinka (który pojawia się w trakcie opisywanej sytuacji) prowadzi pozornie jedynie teoretyczną dyskusję o losie byłych więźniarek obozów, po to m.in., aby dowiedzieć się, że Vilma nie odsłoniła przed małżonkiem swojej przeszłości, a wstydzi się jej i boi. Zasadność tajemnicy potwierdza sam małżonek Vilmy, z teatralną dezynwolturą dokonujący dobitnych moralnych ocen lagrowych przymusowych prostytutek. Toteż Grabner może wyjść z mieszkania Jelinków niemal pewien, że była więźniarka nie przekaże informacji o nim prokuratorowi Rošonkowi, który właśnie - w wygłosowej scenie sztuki - kontaktuje się z Vilmą. Czy to się stanie - nie wiemy, zakończenie dramatu jest otwarte. Przekonani natomiast jesteśmy, że przed Vilmą odsłoniła się istota nowej opresji - nie tylko jej medyczni pacjenci, sąsiedzi, znajomi i przyjaciele najpewniej odwrócą się od niej. Zrobi to również jej rodzina, jeśli tylko Vilma ujawni swoją przeszłość.

Lalka $z$ tóżka $n r 21$ to dramat o strukturze wielokondygnacyjnej, ale i satysfakcjonujący artystycznie. Lebović porusza tu co najmniej trzy główne zagadnienia: wyzwań (prawnych, etycznych, ale i czysto językowych), jakie stanęły przed powojennym systemem sądowniczym, kwestię wiktymizacji oraz splecionej z nią opresji heroistycznej, która występując w genderowych wersjach, dla Vilmy przewidziała rolę „esesmańskiej kurwy”.

W przypadku powojennej Jugosławii środowisko opresji stanowiła pamięć o doświadczeniu wojennym, obozach i Zagładzie usankcjonowana przez ideę „braterstwa i jedności” (bratstvo i jedinstvo). Po zerwaniu w 1948 roku współpracy między przywódcą Jugosławii Titą a Stalinem i Kominformem socjalistyczna federacja jugosłowiańska prowadziła własną politykę, odrębną od obowiązującego w Europie Wschodniej komunistycznego wzorca, skoncentrowaną na budowaniu poczucia wewnętrznej integracji. Odpowiadała jej dosyć liberalna artystycznie, wyłączona z realizmu socjalistycznego, skupiona na antyfaszyzmie polityka kulturalna, której jednym z głównych celów było niwelowanie konfliktów etnicznych. „Braterstwo i jedność” oznaczały zatem ujednolicenie formuły pamięci zbiorowej, skupienie się na heroicznej 
narracji, najlepiej o doświadczeniu partyzanckim, które było udziałem samego Tity, i podporządkowanie modelowi martyrologiczno-heroicznemu uświęcającemu ofiary faszyzmu ${ }^{23}$.

Belgijski badacz Stijn Vervaet, powołując się na słowa Jovana Byforda, przedstawił strategię historiografii jugosłowiańskiej dążącej do wypracowania ujednoliconej kultury pamięci. Niezależnie od tego, że w trakcie II wojny światowej, na terenie późniejszej socjalistycznej Jugosławii, więcej osób zginęło w wyniku między- i wewnątrzetnicznej przemocy niż z rąk niemieckich nazistów i ich sojuszników, pomniki stawiano tam bohaterom partyzanckiej rewolucji i ofiarom faszyzmu, zaś poświęcone im powieści i filmy stały się najpopularniejszym medium narracji historycznejej.

Nie jest, rzecz jasna, właściwością jedynie tego obszaru unifikowanie kultury pamięci. Europa Wschodnia doby komunizmu również dysponowała stosowanym praktycznie, tzn. w ramach polityki kulturalnej, modelem. W różnym okresie wymontowywano z niego doświadczenie Zagłady, propagowano etos romantyczny, dla kobiet zaś - w wypadku naszej rodzimej kultury - przewidziano kryterium dobrej Polki. Wygładzona pamięć kolektywna jest restrykcyjna wobec odstępstw. Praxis nie dyktuje tu reguł, wręcz odwrotnie. Indywidualne doświadczenie, które przez swoją nietypowość, złożoność albo drastyczność odbiega zbyt daleko od dominującej reguły, znajduje się na pozycji straconej i nie ma prawa głosu w jednolitym chórze pamięci. Trafnie pisał o niechęci „przyjmowania do wiadomości tych informacji, które łamały umowę o świętości męczenników" i fikcyjności wspólnoty doświadczeń Jerzy Jedlicki w Dziejach doświadczonych i dziejach zaświadczonych ${ }^{25}$.

A więc właśnie wtedy, kiedy wszystko ginie i kiedy horyzont życia skraca się do jednego tygodnia, do najbliższej wybiórki, właśnie wtedy poczucie historycznej c i ą g ł o ś c i, niewzruszonego trwania świata, kultury, narodu staje się oczywistością założoną. To, co jest, jest tylko przerwą w istnieniu świata ludzkiego, który powstanie na nowo, odkopie palimpsesty

Więcej na temat polityki kulturalnej oraz tabuizowanych po 1948 roku wątków w dyskursie oficjalnym w Jugosławii, m.in. o obozie dla przeciwników politycznych Tity, zob. K. Taczyńska Dowcip trwający dwa i pół roku. Obraz Nagiej Wyspy w serbskim dyskursie literackim i historycznym końca XX i początku XXI wieku, DiG, Warszawa, Bellerive-sur-Allier 2016.

S. Vervaet Staging the Holocaust..., s. 230-231.

J. Jedlicki Dzieje doświadczone i dzieje zaświadczone, w: Dzieło literackie jako źródło historyczne, Czytelnik, Warszawa 1978, s. 347. 
e p o ki pi e ców i będzie usiłował zrozumieć. Ten świat nie będzie się składał z ludzi, którzy przeżyli wspólny los. Albowiem nie ma wspólnego losu. Wspólne jest to tylko, że ludzie nie tworzą już historii, tylko są przez nią miażdżeni²6.

W perspektywie politycznych założeń heroicznej pamięci zbiorowej Lalka $z$ tóżka numer $21 \mathrm{i}$ inne dramaty Lebovicia wyróżniają się jako kontrowersyjne i prowokacyjne. Jego ujęcie doświadczenia wojny nakłuwa naprężoną i pozornie gładką powierzchnię narracji heroicznej i wykazuje jej nieciągłość. Prezentuje bohatera poddanego sytuacji przymusowej, w której nie istnieje wolny wybór, a decydująca pozostaje wola życia. Już pobieżne spojrzenie na Lalkę z tóżka numer 21 pozwala sądzić, że sztuka ta, choć powstała w socjalistycznej Jugosławii i napisana przez pisarza serbskiego, nie odnosi się jedynie do lokalnej kultury pamięci i wykracza poza współczesną mu politykę historyczną. Co więcej, dawka moralnego niepokoju narzuconego właśnie dzisiejszemu polskiemu odbiorcy przez twórczość Lebovicia okazuje się zadziwiająco aktualna.

Wyeksponowany dzięki procesom norymberskim i głośnemu procesowi Eichmanna problem niewydolności litery prawa wobec zbrodni nazistów to temat już wielostronnie opracowany i naukowo skonceptualizowany. Jednak nie we wszystkich aspektach. Zagadnienie „szarej strefy”, by użyć określenia Primo Leviego ${ }^{27}$, czyli niejednoznaczności podziału na ofiary i sprawców, wywoływał już wspomniany wyżej dramat Lebovicia Niebiański oddziat, a podejmuje również sztuka Wiktoria (Viktorija) z $1968 \mathrm{roku}^{28}$. W Niebiańskim oddziale uwaga autora koncentruje się na historii Żydów z Sonderkommando, pokazuje on, iż sytuacja uwięzienia, która z definicji jest przymusowa, likwiduje ewentualność oceniania jej jako sytuacji wolnego wyboru, w zasadzie uniemożliwia też osądzenie.

Dramat Wiktoria nawiązuje do dwóch wydarzeń: buntu Sonderkommando i masakry na więźniarkach francuskich dokonanej w podobozie Auschwitz Budach i przedstawia proces sądowy dwóch szefów obozu. Oba te zdarzenia sfikcjonalizowane powracają w dramacie Lebovicia jako kolejny pretekst do rozważenia sytuacji „wyboru bez wyboru”. Członkowie oddziału „hajcerów”

\footnotetext{
26 Tamże, s. 345-346. Zaznaczenia (rozstrzelenia) znajdują się w tekście oryginalnym. 
pokazani jako rebelianci wychodzą poza romantyczny etos buntu i ucieczki i - aby powstanie mogło się rozpocząć - poświęcają życie jednego wybranego przez nich więźnia. W procesie stają zaś jako oskarżyciele komendanta sądzonego za zabójstwo. Drugie zdarzenie (masakra więźniarek w Budach) stało się kanwą kreacji historii więźniarek z lagrowego „domu lalek”, które na toczącej się po dwóch dekadach od wyzwolenia rozprawie sądowej nie są zgodne co do wersji przeszłości. Dokonanie manipulacji na faktach okazuje się potrzebne nie tylko oskarżonemu o mord komendantowi, ale i niektórym ze świadczących w jego procesie uczestniczek zdarzeń. Wbrew prawdzie utrzymują one, że istniał wśród nich ruch oporu, który został zdławiony. Zaś dla oskarżonego kłamstwo jest o tyle konieczne, że prezentuje go jako funkcjonariusza na służbie, działającego w ramach obowiązującego prawa. Fałsz heroicznej wersji historii służy więc obydwu stronom, a zatarciu ulega granica między katem i ofiarą. Warto dodać, że wystawienie obydwu dramatów wywołało wielką falę, nieraz niewybrednej krytyki, sprowadzającej się do stwierdzenia, że oddanie tragedii bez katharsis jest bezcelowe ${ }^{29}$.

Problem opresji heroistycznej, która po latach godzi w "seksualne kolaborantki" - bo tak czasem określa się przymusowe prostytutki - Lebović odsłonił nie tylko w Wiktorii i Lalce z tóżka numer 21. W 1998 roku podczas pobytu w Izraelu napisał sztukę Żotnierz i lalka (Vojnik i lutka). Akcja dramatu toczy się w latach 70. XX wieku. Prezentuje on historię byłych więźniarek burdelu dla esesmanów, które mogą stanąć jako świadkinie oskarżenia w procesie sądowym jego dawnego komendanta. Jednak kobiety zostają poddane presji samego byłego szefa, członków własnych rodzin i współwięźniarek. Choć sztuka ta powstała na zamówienie telawiwskiego teatru Bet Lessin, nie została tam jednak wystawiona, dyrektor artystyczny nalegał na dokonanie zmian w tekście, zaś Lebović nie wyraził na to zgody. Tekst sztuki został opublikowany w Serbii, nie został tam jednak dotąd zrealizowany jako spektakl ${ }^{30}$.

Frazesem bez mocy argumentu jest już dzisiaj formułowane przez wielu zbrodniarzy nazistowskich w trakcie ich procesów sądowych, stwierdzenie, że ,jedynie wykonywali rozkazy”. I w Lalce z tóżka numer 21 powraca taka kwestia, co więcej odsłania pewne zbieżności w losie katów „z rozkazu” i ofiar - prostytutek, również „z rozkazu”. Posłuchajmy rozmowy Grabnera szantażującego Vilmę.

29 Zob. tamże, s. 238.

30 J. Ahmetagić Dramska slika problema viktimizacije, "Sarajevske Sveske” 2006 nr 11/12, http:// www.sveske.ba/bs/content/dramska-slika-problema-viktimizacije (11.02.2018). 
GRABNER: [...] Ale, pozwoli pani, dziewczyna, która posłużyła jako seksualne katharsis setkom zniesławionych żołnierzy - tak, to już jest coś, o czym warto pisać i mówić!

VILMA: Ta dziewczyna nie robiła tego z własnej woli! Pan najlepiej wie, że była zmuszona!

GRABNER: I co z tego? Czy Emil Grabner z własnej woli został szefem obozowego burdelu? Chyba pani nie myśli, że to był jego cel życiowy? On też robił to, co robił pod przymusem... Ponieważ rozkazy przełożonych też są rodzajem przymusu.

Ten dialog modelowo wręcz prezentuje nieprzystawalność etycznych modeli kulturowych i logiki argumentów sprzed Auschwitz, a nawet języka służącego charakterystyce zbrodni do niej samej. Jednak Vilma wpada w pułapkę takiego uzasadnienia. Grabner wykazuje jej, i jego dowodzeniu od strony logicznej nie można niczego zarzucić, że obydwoje działali pod podobnym przymusem. Zręcznie tworzy on więź współsprawstwa ofiary z katem - zupełnie podobny mechanizm obezwładnia morale więźniów z Sonderkommando. Esesman zdaje sobie sprawę z siły tej więzi: „GRABNER (off): Czy to możliwe, że mnie pani zapomniała, Vilmo? A byliśmy długo razem. Nie, «razem» to nie dobre słowo. Byliśmy czymś więcej niż to". Trafnie ocenia, że Vilma w roli ofiary pojmuje tę więź jako konieczność kooperacji w sytuacjach społecznych. Grabner plastycznie przedstawia Vilmie aspekty opresji, w jakiej się ona znajduje.

GRABNER: Ja panią ostrzegam: rozprawa nie będzie tajna. Ten proces będzie zabarwiony politycznie i niektórym będzie zależeć na tym, by zapewnić mu rozgłos. A ma pani pojęcie, co dziś znaczy rozgłos? (Wstaje i zaczyna chodzić po pokoju) To prawda, prasa nie jest zachwycona, gdy się jej proponuje procesy związane z obozami koncentracyjnymi. Powtarza się zawsze to samo, czyż nie? Komory gazowe, eksperymenty in vivo, masakry - to już się staje nudne. Ale "przypadek Grabnera”, niech pani uważa, Vilmo, ten przypadek to coś innego. W takim procesie, przyzna pani, byłoby dosyć sensacji, kwestii drażliwych, a nawet bezwstydnych. Tak, tak, takich właśnie najwięcej. No, proszę pani, czy istnieje coś bardziej perwersyjnego od seksu i brutalności? Dom publiczny w obozie śmierci! Cudowna niezgoda, nie ma co? Tu wyobraźnia może rozwinąć skrzydła... (Podchodzi do Vilmy i schyla się nad nią) Dziennikarzy wszystko będzie interesować, wszystko: 
najdrobniejsze, najbardziej intymne szczegóły. Ilu klientów miała pani dziennie... ilu na godzinę... jak oni reagowali... jak pani... Będą panią pytać, kiedy czuła pani obrzydzenie, a kiedy przyjemność... będą pytać o wszystko!

Najstraszniejsze jest to, że Grabner ma rację. Czasy lagrów były okresem jawnego okrucieństwa, ale i powojenną współczesnością rządzą wystarczająco według niego bezwzględne mechanizmy, dlatego lekceważy on odwołania do przeszłości: „Zostawmy w spokoju tamte czasy! My zależymy od tych, w których teraz żyjemy! Zrozumiała pani?”.,Ten czas”, czyli pragnienie Vilmy tzw. normalnego życia, może zostać spełnione tylko za cenę tymczasowego zapominania, udawania, że „to mi się nie przydarzyło” i skrytego kompensowania tej przeszłości przeświadczeniem, że jej główny sprawca Grabner już nie żyje. On sam z łatwością szacuje, jak wątłe są fundamenty życiowej stabilizacji byłej więźniarki, dlatego bez trudu buduje w niej poczucie winy. Jest przekonany i uświadamia to Vilmie, która twierdzi, że pamięta wszystko, że jej pamięć musiała stać się wybiórcza i oszukańcza:

VILMA: Pamiętam, Grabner. Może być pan pewien, że wszystko zapamiętałam.

GRABNER: Próbuję zgadnąć, o czym pani myśli. Ale jestem pewien, że jednak nie zapamiętała pani wszystkiego. Nie wierzę, że była pani taka okrutna wobec siebie. Lub, być może, się mylę?

VILMA: Myli się pan, Grabner. Pamiętam wszystko.

GRABNER: Przykro mi to słyszeć. To znaczy, że 20 lat pani niepotrzebnie męczyła samą siebie?

VILMA: Inaczej się nie dało.

GRABNER: Gdyby inaczej się nie dało, pani nie byłaby teraz panią doktor i nie miałaby takiej idealnej pary dzieci.

VILMA: A co, według pana, bym miała?

GRABNER: Nic, Vilmo. Nic, poza wyrzutami sumienia.

VILMA: Z jakiego powodu?

GRABNER: Z jakiego powodu? Niewygodne pytanie, Vilmo. Przykro mi, ale jestem pani winny odpowiedź. Dlatego że była pani nierządnicą... Żeby uzupełnić: esesmańską nierządnicą.

„Pamięć wszystkiego" uniemożliwiłaby Vilmie odniesienie sukcesu osobistego i zawodowego. Aby mogła ona stać się czułą matką i szanowaną lekarką, 
musiała dokonać czegoś w rodzaju heroizacji osobistej pamięci, usunąć z niej poczucie hańby i poniżenia, a oprzeć się na poczuciu swojego hartu ducha i poświęcenia. Grabner insynuuje więc, że Vilma jest podobnie fałszywa, jak społeczeństwo domagające się takiej właśnie, oczyszczonej z kontrowersyjnych składników pamięci.

Warto zwrócić uwagę, że w powojennych realiach, które osaczają Vilmę, chodzi o politykę pamięci w konkretnej wersji genderowej - a patrząc szerzej - kulturę patriarchalną, która dyktuje obowiązujące kody pamięci. Dla Vilmy przewidziała ona raczej rolę samobójczyni ocalającej czystość niż przymusowej prostytutki ocalającej życie. Nic nie pozostaje z prostodusznych oczekiwań, że współczesność zadośćuczyni traumie. Nie tylko żłobi ona jeszcze głębiej rany, ale i dowodzi, że zadośćuczynienie - w takiej kulturze - nie jest możliwe.

W najnowszych opracowaniach historycznych i antropologicznych znajdujemy coraz więcej informacji na temat literacko przedstawiony też przez Yehiela De-Nura w Domu lalek (pierwodruk 1956). Trudno nie zauważyć, że realia według Ka-tzetnika przypominają te przedstawione przez Lebovicia.

Codziennie o drugiej po południu przyjeżdżają tu z pobliskich punktów tranzytowych niemieccy żołnierze, skierowani na front, aby zabawić się z dziewczętami z Domu Lalek. Dziewczęta mają obowiązek dać z siebie wszystko, żeby ich znamienici goście byli zadowoleni. Jeśli gość nie jest zadowolony z zabawy, to może podać numer obsługującej go dziewczyny w portierni. Po trzech takich raportach los dziewczyny jest przesądzony, gdyż nie potrafiła odpowiednio docenić honoru, jaki ją spotkał, i zraniła subtelne uczucia niemieckiego wojownika. ${ }^{31}$

GRABNER: Dokładniej z dwudziestoma dziennie. Średnio!

JELINEK: Słyszysz, Vilmo? Z dwudziestoma dziennie!

GRABNER: A to jest - trzymając się średniej - w ciągu roku okrągłe 7 tysięcy perfekcyjnie obsłużonych esesmańskich chłopców. [...] Ale w „Domu Lalek” istniały zasady. I to bardzo systematyczne zasady. Każdy odwiedzający oceniał swoją lalkę. Wie pan, jak w tej dziecięcej grze: ciepło... zimno... I cóż, lalka, która dostała trzy negatywne oceny... no, ona odpadała... Bez prawa do egzaminu poprawkowego, oczywiście. 
Oficjalna strona internetowa Muzeum Auschwitz-Birkenau od dekady prezentuje elementarne dane na temat prostytucji w tym obozie ${ }^{32}$.

Według niektórych oświadczeń puff działał trzy godziny dziennie, według innych dwie. Nie mamy więc pewności, na ile zezwalano wizyt. W innych obozowych domach publicznych, do których wysyłano więźniarki z Ravensbrück, tych tzw. szycht było więcej. ${ }^{33}$

Pozostawmy historykom ustalenie szczegółowych, faktograficznych danych. Dramat Lebovicia pozostaje źródłem historycznym nie w sensie dosłownym, ale przemawia kamiennością doświadczenia kobiety poddanej w lagrze seksualnej eksploatacji, a potem „wolnościowemu” przymusowi milczenia. W symbolicznej opowieści Vilmy zawierają się losy tych kobiet, które nie zaprotestowały śmiercią przeciwko seksualnej przemocy (a w obozie koncentracyjnym mogła ona mieć różne, nie tylko „usankcjonowane” instytucją puffu formy ${ }^{34}$ ) i które później pozwoliły wtrącić się w powinność milczenia. Lebović uchwycił fatalny łańcuch sprzęgający w jednym ludzkim życiu, jak Vilmy właśnie, wojenną traumę i powojenną opresję, wytworzoną przez wiktymizującą kobietę normę kulturową (bo czy nie z tego głównie powodu Vilma milczy przed mężem o swojej przeszłości?) i dominującą normę pamięci heroicznej.

Obyczajowość i historyczna pamięć zbiorowa egzystują w konkretnym, niekoniecznie jednowymiarowym i ciagle takim samym wymiarze

Domy publiczne w Auschwitz, Miejsce Pamięci i Muzeum Auschwitz-Birkenau, 26.07.2007, http://auschwitz.org/muzeum/aktualnosci/domy-publiczne-w-auschwitz,545.html (22.02.2018).

33 Jarosław Zalesiński rozmawia z Agnieszką Weseli, Noce i dnie w obozie Auschwitz. Problem obozowej prostytucji został podjęty w rozproszonych opracowaniach naukowych, ale i przez publicystykę historyczną, zob. np. A. Weseli Puff w Auschwitz, „Polityka” 2008 nr 27, s. 72-74; J. Ostrowska, M. Zaremba Do burdelu marsz, "Polityka” 2009 nr 22, s. 70-72; F. Piper Auschwitz prisoner labor: the organization and exploitation of Auschwitz Concenteration Camp Prisoners as Laborers, trans. W. Brand, Auschwitz-Birkenau State Museum, Oświęcim 2002. Monografia na temat przymusowej prostytucji w lagrach ukazała się w połowie września 2018, J. Ostrowska Przemilczane. Seksualna praca przymusowa w trakcie Il wojny światowej, Warszawa 2018. Istnieje również niemieckie opracowanie szeroko podejmujące ten problem, zob. M. Röger Wojenne zwiq̨zki: Polki i Niemcy podczas okupacji, przeł. T. Dominiak, Świat Książki, Warszawa 2016.

34 Bogatym źródłem wiedzy o seksualnym sadyzmie wobec kobiet więzionych w głównych KL i ich podobozach są zarchiwizowane relacje/zeznania byłych więźniarek. 
politycznym - dlatego serbski dramat z lat 6o. osadzony w kulturze pamięci socjalistycznej Jugosławii pozostaje czytelny i aktualny również w Polsce najbardziej współczesnej. Sumarycznie rzecz biorąc, Vilma egzystuje pod groźbą śmierci, ciśnieniem represji bądź - później - w opresywnym środowisku symbolicznym skazującym ją na uległość. Lebović wydobywa problem wszystkich pamięci zdominowanych przez kolektywny, społeczny i polityczny nakaz. W los „nieheroicznej”Vilmy wpisują się milczące ofiary wszystkich wojennych gwałtów: przymusowe prostytutki burdeli zakładanych przez Niemców w okupowanej Europie, Chinki i Koreanki z domów publicznych prowadzonych przez Japończyków, wszystkich narodowości ofiary gwałtów dokonywanych w lagrach przez ich zachodnich i wschodnich wyzwolicieli, kobiety zgwałcone w drodze powrotnej do domu ze zdobywanych przez aliantów i Sowietów Niemiec, kobiety gwałcone w latach 90. w trakcie konfliktów etnicznych w byłej Jugosławii. Ale nie tylko one. Historia Bałkanów przerażająco udowodniła, że narzędzia terroru nie dezaktualizują się równolegle do postępu cywilizacyjnego. Ostracyzm społeczny też nie wytraca swojej zaciętości w tempie odpowiadającym rozwojowi nowoczesnej myśli humanistycznej i technologicznej.

Przymusowa prostytucja kobiet w lagrach wciąż pozostaje ślepą plamką pamięci, niestety również historiografii, dramaty Đorđa Lebovicia są jej kruchą artystyczną przeciwwagą. Jak zauważa Agnieszka Weseli:

...jeszcze w 1993 r. niemiecki historyk nazywał kobiety z obozowych domów publicznych „kurwami”, a inny w 1979 r. zaliczył dom publiczny do „działalności kulturalnej” w obozie. Polski autor książki na temat pracy przymusowej w obozie Auschwitz-Birkenau widział dom publiczny jedynie jako element systemu nagród.

Kiedy mówi się o wojnie, nie mówi się o kobietach ani o przemocy w sferze seksualnej. Kiedy mówi się o przemocy seksualnej, myśli się o winie ofiar. A kiedy myśli się o prostytucji, nie uważa się jej za pracę. W Niemczech i Austrii historyczki zbierają relacje byłych pracowniczek domów publicznych i badają ten temat od końca lat 8o. W Polsce wciąż lepiej go nie dotykać: mit Auschwitz jako miejsca podniosłej śmierci jest za silny. Kwerendy, które zaczęłam prowadzić w oświęcimskim archiwum w 2002 r., były wysiłkiem pionierskim.

Władze żadnego z wymienionych krajów do dziś nie uznały pracy kobiet w nazistowskich domach publicznych za przymusową. Nie wypłacono więc należnych odszkodowań kilkudziesięciu tysiącom kobiet, 
w tym ok. 150 byłym pracowniczkom obu domów publicznych na terenie obozu Auschwitz-Birkenau ${ }^{35}$.

Dochodzimy tutaj do sedna, czyli lalki w Lalce z łóżka $n r$ 21. Nie tylko tytuł, już i czołówka spektaklu sygnalizuje jeden z głównych problemów dramatu - uprzedmiotowienie kobiet, ekstremalne i widoczne gołym okiem w aktach przemocy wojennej i obozowego terroru (lalka jako sexy doll) i ukryte, ale dotkliwe, występujące jako kulturowa opresja w czasach powojennej, do pewnego stopnia teoretycznej wolności. Przeczytajmy wersy otwierające sztukę.

Zbliżenie na kobiece oczy, ogromne, wytrzeszczone, nieruchome. Rozpoczynają się silne akordy marszu wojskowego, to znaczy gwizdanie, bez muzycznego akompaniamentu. Kamera powoli wycofuje się i jej spojrzenie chwyta wielką kobiecą lalkę, całkowicie nagą. Zaczyna się czołówka. Gdy pojawiają się napisy czołówki, spojrzenie kamery, z tyłu, prześlizguje się przez szereg nagich lalek ułożonych obok siebie. Marsz wojskowy się stopniowo ucisza. Czołówka skończyła się. Spojrzenie kamery zatrzymuje się na jednej lalce i powoli zbliża się do jej głowy.

Czołówka ta stanowi wręcz kontekst idealny dla Męskich fantazji Klausa Theweleita, w którym to studium współczesny niemiecki badacz analizuje nazistowską kulturę patriarchalną. Dowodzi on - by streścić sens obszernej książki w jednym zdaniu - że głównym powodem przedmiotowego traktowania kobiet przez Niemców była surowa dyscyplina, w dużej mierze wojskowa, której byli długofalowo poddani. Wykreowany przez Lebovicia rząd nieruchomych lalek atakowanych obcesowymi dźwiękami marsza wojskowego może być metaforą tej sytuacji.

Vilma jako lagrowa prostytutka jest gwałcona wielokrotnie, ale kiedy kończy się wojenny horror, nadal pozostaje „nieruchoma”, nie może oczekiwać zadośćuczynienia. Co więcej, nie domaga się też, aby jej wysłuchano, zrozumiano i uznano ją za ofiarę. Milczy o swojej traumie nawet przed najbliższymi. Taki schemat „nieruchomości” zgwałconych kobiet potwierdzają współczesne badania medyczne psychologicznych konsekwencji

35 A. Weseli Puff w Auschwitz, „Polityka” 4.11.2009, https://www.polityka.pl/tygodnikpolityka/historia/260561,1,puff-w-auschwitz.read (22.02.2018). 
gwałtu ${ }^{36}$. Mówi też o nim cytowana już historyczka, badaczka relacji osobistych byłych więźniarek.

Wśród tych parudziesięciu wspomnień, w których napomyka się o puffie, nie ma ani jednej relacji którejś z tych kobiet, prawda? Żadna z nich po wojnie nie zabrała głosu. Nietrudno zrozumieć dlaczego. Natomiast od końca lat 8o. mówią o swoich doświadczeniach nieliczne Niemki z Ravensbrück, zatrudniane w domach publicznych nie tylko dla więźniów, ale i np. dla Wehrmachtu. System domów publicznych był ogromny, obsługiwał rozmaite grupy, które trzeba było motywować. ${ }^{37}$

I w dramacie Lebovicia pojawia się taka kwestia:

VILMA: Na szczęście, nie tylko ja wyszłam żywa z „Domu Lalek”!

GRABNER: Wiem, Vilmo. Ale, poza nas dwojgiem, kto jeszcze o tym wie? VILMA: Pana byłe lalki!

GRABNER: Lalki Grabnera nie istnieją. Ja nigdy o nich nie słyszałem. W ciągu ostatnich 20 lat ani jedna się nie zgłosiła.

Lebović gra metaforą lalki, jej nieruchomość to prawie nieistnienie, a to jest jeszcze więcej niż uprzedmiotowienie. Vilma - porzućmy pozorny, „zewnętrzny” obraz jej osoby - jest wciąż lalką bez możliwości wyboru. Zatem zależy od swojej przeszłości, w której podlegała Grabnerowi i eksploatującym ją żołnierzom, a dwadzieścia lat później zależy od obowiązującej normy, a dokładniej od patriarchalnej opinii społecznej i współmałżonka. Jelinek ze swą łatwością ferowania surowego osądu nie pozostawia przecież złudzeń co do swojej postawy:

JELINEK (ironicznie): Ależ „biedaczki” cierpiały.

VILMA: Dlaczego jesteś zgryźliwy? Przecież całe szczęście nie leży w sytości.

JELINEK: Teraz to łatwo powiedzieć... Ale wątpię, że w obozie tak mówiłaś.

36 Zob. Przestępstwa seksualne: ujęcie psychologiczne, prawne i kryminalistyczne, red. P. Herbowski, W. Krawczyk, D. Słapczyńska, Difin, Warszawa 2016; G. Vigarello Historia gwałtu: od XVI do XX wieku, przeł. A. Leyk, Aletheia, Warszawa 2010.

37 Jarosław Zalesiński rozmawia z Agnieszką Weseli, Noce i dnie w obozie Auschwitz. 
VILMA: W obozie o tym w ogóle nie rozmyślałam.

JELINEK: Ale te szmaty musiały o tym rozmyślać!

VILMA (ostro): Nie nazywaj ich tak!

JELINEK: A jak mam je nazywać?

GRABNER: Może „nierządnica” jest łagodniejszym wyrazem.

Kolejną metaforą uprzedmiotowienia są zatem „te szmaty”. Grabner wydaje się tu dużo bardziej przenikliwy od Vilmy, która spodziewała się innego zachowania swego męża:

VILMA: Pozwoli pan, ja swojego męża znam lepiej niż pan!

GRABNER: Nie zaprzeczam! Tylko ja też coś o nim wiem: on jest mężczyzną!

VILMA: Nie wszyscy mężczyźni zostali stworzeni według pana szablonu. GRABNER: To nie mój szablon. To nawet nie jest szablon. To jest aksjomat. Chciałaby pani może to sprawdzić?

„Aksjomat" patriarchalizmu spełnia swoją funkcję. W innym miejscu sztuki przeczytamy: „JELINEK: Vilma całkowicie się ze mną zgadza. / GRABNER: I musi. Ona jest pańską żoną".

Uprzedmiotowienie kobiety połączone jest tu jeszcze z wyeksponowaniem zapotrzebowania kultury na sensację, spektakl, widowisko, na „soczyste mięso", jak to określa Grabner, które stanowić ma obozowa przeszłość Vilmy. („Pani ich zmusi? Pani? Pani ich przymusi, żeby zrezygnowali z soczystego mięsa i zadowolili się nieświeżymi okruchami?”).

Kobieca trauma (symbolicznej lalki) nie wniknęła do pamięci zbiorowej społeczeństwa i nie stała się elementem jego tożsamości, tożsamość zbiorowa dokonała uniku, wymknęła się temu dosyć indywidualnemu doświadczeniu. Można też powiedzieć, że wzbroniła mu do siebie wstępu. Nawet słowo „lalka” w znaczeniu, w jakim występuje u Lebovicia, Yehiela De-Nura i innych, a także języku niemieckim i angielskim, nie weszło do frazeologii języka polskiego.

Lalka $z$ tóżka numer 21 jest dramatem oszczędnym w środki wyrazu, rzec można awidowiskowym i bez efektów specjalnych. Ale ta surowość eksponuje też tragizm i powagę tematu. Spektakl wyobrazić sobie można jako zagrany jedynie mimiką, prostym gestem, intonacją. Wydaje się, że wybór Haliny Mikołajskiej, znakomitej aktorki i reżyserki teatralnej, do roli Vilmy był doskonały. A figura lalki, rekwizyt w postaci nagiej lalki, chcąc nie chcąc, 
kojarzący się ze sklepem typu sex shop wystarczająco spektakularnie dekonstruuje poddany dyskusji przymus heroizmu.

Utopią jest wizja społeczeństwa, którego podstawą integralności jest poczucie wspólnej traumy i przymus posiadania heroicznej biografii. Lebović wychodzi od takiego przekonania i zdaje się wskazywać kierunek myślenia o kulturze i dominujących trendach pamięci nie jako niezmiennym paradygmacie o charakterze normatywnym, ale sferze podlegającej koniecznym korektom dyktowanym przez praktykę życia, również z jej jednostkowością. Można powiedzieć, że autorowi chodziło o podkreślenie tego, co w kulturze dysonansowe, niepokojące, niejednoznaczne, co nie podlega obyczajowo-politycznej sztancy i dyrektywom objęcia dyskrecją fragmentów doświadczenia oraz o wywalczenie uwagi dla tych przypadków. Dramat pozostawia nas z pytaniem o świadectwo i empatię dającą poczucie wspólnoty, o nas jako homo empathicus. Zwróćmy się raz jeszcze do profesora Jedlickiego: „Doświadczenia zdawały się niemożliwe do przekazania, a jednak wiadomość musiała zostać doniesiona do innych wyłączonych światów. Więcej niż wiadomość - świadectwo"38. Jaką pamięć ufundujemy na świadectwach, również „lalek”, które nam przekazano, zależy od nas.

38 J. Jedlicki Dzieje doświadczone i dzieje zaświadczone , s. 346. 


\section{Abstract}

\section{Barbara Czarnecka}

JAGIELLONIAN UNIVERSITY (CRACOW)

\section{Katarzyna Taczyńska}

ADAM MICKIEWICZ UNIVERSITY (POZNAŃ)

Đorđe Lebovićs The Doll from Bed 21: WarTrauma and the Oppression of Freedom

This article examines the play The Doll from Bed 21 [Lutka sa kreveta broj 21] by Đorđe Lebović, who had co-authored A Heavenly Detachment (Nebeski odred, 1956) with Aleksandar Obrenović - the first play to address the Holocaust in Socialist Yugoslavia, which was first televised in Yugoslavia in 1966. In Poland the play was not performed, but in 1970 TVP showed a performance based on Lebović's text. The play tackles forced prostitution in the camps as well as the women's experiences after the war, including their stigmatization and hierarchization as victims as well as the tabuization of the entire subject. The main themes are the legal, ethical and often linguistic challenges faced by the postwar judicial system, as well as questions of victimization and heroical gender oppression.

\section{Keywords}

Đorđe Lebović, drama, Holocaust, forced prostitution, gender oppression 